\title{
Oyster Mushroom (Pleurotus pulmonarius) Production Using Different Substrates Under $27.3^{\circ} \mathrm{C}$ Average Temperature
}

\author{
${ }^{1}$ Alifahmie A. Magolama \\ Assistant Professor IV, College of Agriculture, Mindanao \\ State University- Main Campus \\ Marawi City, 9700, Lanao del Sur, Philippines
}

\author{
${ }^{2}$ Sheila G. Griengo \\ Assistant Professor IV, College of Agriculture, Mindanao \\ State University- Main Campus \\ Marawi City, 9700, Lanao del Sur, Philippines
}

\author{
${ }^{3}$ Abdani D. Bandera \\ Assistant Professor I, College of Agriculture, Mindanao State University- Buug Campus \\ Buug, Zamboanga Sibugay, 7009, Philippines
}

\begin{abstract}
The study was conducted in an average temperature of $27^{\circ} \mathrm{C}$. Objectives were to determine the yield performance of oyster mushroom using different substrates and substrates' combination; to determine if there is a significant difference on the yield performance of oyster mushroom using different substrates and substrates' combination; and to identify which of the different substrates and their combination performs best in oyster mushroom production. The experiment was laid out using Completely Randomized Design (CRD) with an area of $30 \mathrm{~m}^{2}$. Four treatments were used and replicated five times. Sawdust, corn cob and rice straw were the substrates used in this study. Treatments were: $T_{1}\left(100 \%\right.$ rice straw), $T_{2}(100 \%$ corn cob), $T_{3}\left(100 \%\right.$ sawdust), and $T_{4}(33.33 \%$ rice straw + $33.33 \%$ corn cob $+33.33 \%$ sawdust). Results of the study showed that there was a highly significant difference on the average number and total number of oyster mushroom during the first harvest. However, the average weight and total weight of oyster mushroom were not significantly different. The average number, average weight, total number, and total weight were not significantly different during the second to fifth harvest. Based on the results of the study, the adoption of $T_{3}$ to obtain more number of oyster mushroom per fruiting bag per treatment is highly recommended to improve the production in the locality.
\end{abstract}

Keywords:- Oyster Mushroom; Pleurotus pulmunarius; Complete Randomized Design; Substrate; Corn Cob, Rice Straw, Sawdust.

\section{INTRODUCTION}

The production of oyster mushroom and other strains is observed high in terms of consumers' demand in the market. Its nutritive value boosts the demand for the commodity. In addition, the demand for the produce attracts farmers to learn variables affecting mushroom production. However, farmers still struggle in determining appropriate substrates to be used to yield high. Thus, this study helps growers which local substrates is best to improve production.
Mushroom is now found an important commodity due to its nutritive value. [37] reported that Coprinus atramentarius (Bull.: Fr.) Fr. contain $24 \%$ of carbohydrate on dry weight basis. The mannitol, also called as mushroom sugar constitutes about $80 \%$ of the total free sugars, hence it is dominant [125], [129]. [87] revealed that a fresh mushroom contains $0.9 \%$ mannitol, $0.28 \%$ reducing sugar, $0.59 \%$ glycogen and $0.91 \%$ hemicellose. Carbohydrates of Agaricus bisporus were reported by [28]. In mushrooms, the fat content is very low as compared to carbohydrates. The fats present in mushroom fruiting bodies are dominated by unsaturated fatty acids. [118] determined the fat content of some mushrooms as $2.04 \%$ in Suillus granulatus, $3.66 \%$ in Suillus luteus and $2.32 \%$ in A. campestris. [49] found that mushrooms are rich in linolenic acid. Total fat content in A. bisporus was reported to be 1.66 to $2.2 / 100 \mathrm{~g}$ on dry weight basis [78]. [92] showed that mushrooms have $4.481 \%$ fats on dry weight basis. [61] has revealed a fat content of $11.52 \%$ in the Amanita ceasarea fruiting bodies on dry weight basis. In $100 \mathrm{~g}$ fresh matter of $A$. bisporus (Lange) Sing and Pleurotus ostreatus (Jacq: Fr.) Kumm, the content of fatty compounds were reported to be 0.3 and $0.4 \mathrm{~g}$ respectively [81], but on dry weight basis, it is 2 and 1.8 g respectively [114]. [2], [81], [111] and [82] worked on the fibre content of different mushrooms. Mushrooms are considered good source of fats and minerals [55]. [135] and [96] showed that fat fraction in mushrooms is mainly composed of unsaturated fatty acids.

[1] found that content of potassium and sodium in $A$. bisporous was 300 and $28.2 \mathrm{ppm}$. respectively. A. bisporus ash analysis revealed high amount of $\mathrm{K}, \mathrm{P}, \mathrm{Cu}$ and $\mathrm{Fe}$ [5]. [62] showed that $M$. esculenta contains $\mathrm{Ca}(0.5776 \mathrm{mg}), \mathrm{P}$ (3.313 mg), Fe (1.213 mg) and K (3.831 mg). [126] showed that $A$. bisporus contains $\mathrm{Ca}(0.04 \mathrm{~g}), \mathrm{Mg}(0.16), \mathrm{P}(0.75 \mathrm{~g})$, $\mathrm{Fe}(7.8 \mathrm{~g}), \mathrm{Cu}(9.4 \mathrm{mg}), \mathrm{Mn}(0.833 \mathrm{mg})$ and $\mathrm{Zn}(8.6 \mathrm{mg})$ per kilogram fresh weight. Mushrooms have been found to accumulate heavy metals like cadmium, lead, arsenic, copper, nickel, silver, chromium and mercury [113], [88], [133], [59], [122], [53], [79]. The mineral proportions vary according to the species, age and the diameter of the fruiting body. It also depends upon the type of the substratum [30]. The mineral content of wild edible 
mushrooms has been found higher than cultivated ones [2], [83], [105].

Mushrooms are one of the best sources of vitamins especially Vitamin B [17], [84], [140], [24], [85]. Vitamin content of edible mushrooms has been revealed by [32], [14] and [75]. [80] gave a comprehensive data of vitamin content of mushrooms and some vegetables. [84] pointed out that wild mushrooms contain much higher amounts of vitamin D2 than dark cultivated A. bisporus. Mushrooms also contain vitamin $\mathrm{C}$ in small amounts [112], [83] which are poor in vitamins $\mathrm{A}, \mathrm{D}$, and $\mathrm{E}$ [5].

Lintzel [73]-[74] suggested that 100 to $200 \mathrm{~g}$ of mushrooms (dry weight) is required to maintain an optimal nutritional balance in a man weighing $70 \mathrm{~kg}$. [13] identified the nutritive value of Pleurotus flabellatus as $0.974 \%$ ash, $1.084 \%$ crude fibre, $0.105 \%$ fat, $90.95 \%$ moisture, $0.14 \%$ non-protein nitrogen and $2.75 \%$ protein. [8] recommended that food value of mushrooms lies between meat and vegetables. [28] found that mushrooms in general contain $90 \%$ water and $10 \%$ dry matter. [92] showed that an average mushroom is about $16.5 \%$ dry matter out of which $7.4 \%$ is crude fibre, $14.6 \%$ is crude protein and $4.48 \%$ is fat and oil. [41] revealed that edible mushrooms were highly nutritional and compared favourably with meat, egg and milk food sources. Of several thousand mushroom species known worldwide, only around 2000 are considered edible, of which about 20 are cultivated commercially with only 4 to 5 under industrial production [23].

Protein is an important constituent of dry matter of mushrooms [2], [4], [34], [38], [140], [24].. Protein content of the mushrooms has also been revealed to vary from flush to flush [28]. [44] showed that protein in A. bisporus mycelium ranged from 32 to $42 \%$ on the dry weight basis. [1] showed $46.5 \%$ protein on dry weight basis in $A$. bisporus. [109] showed 30.16, 28.16, 34.7 and $29.16 \%$ protein in dried mycelium of A. campestris, Agaricus arvensis, $M$. esculenta and Morchella deliciosa respectively. [98] revealed 14 to $27 \%$ crude protein on dry weight basis in A. bisporus, Lentinus subnudus, Calocybe indica and Volvariella volvacea. On dry matter basis, the protein content of mushrooms varies between 19/100 and 39/100 g [132], [17]. In terms of the amount of crude protein, mushrooms rank below animal meats but well above most other foods including milk [21]. On a dry weight basis, mushrooms normally contain 19 to $35 \%$ proteins as compared to $7.3 \%$ in rice, $12.7 \%$ in wheat, $38.1 \%$ in soybean and $9.4 \%$ in corn [28], [72], [10].

[65] showed that mushroom extracts possess DNA protecting properties. G. lucidum extracts can trap number of free radicals [56]. [86] observed antioxidant properties of several ear mushrooms. Many species of mushrooms have been observed to be highly potent immune enhancers, potentiating animal and human immunity against cancer [131], [16], [63], [35]. Tyrosinase from A. bisporus is antioxidant [117]. [69] determined antioxidant activity of $P$. sajor caju. [106] observed that triterpenoides are the main chemical compounds in $G$. lucidium. Camptothecin is responsible for antioxidant properties in G. lucidum [139].

In underdeveloped countries where protein malnutrition has taken epidemic proportions, Food and Agricultural Organization has suggested mushroom foods to solve the problem of malnutrition [120]. [57] revealed that mushrooms cause regression of the disease state. Mushroom medicines are without side effects [108]. [31] showed hundreds of secondary metabolites of fungal origin possessing biological activity. Mushrooms act as biological response modifiers by promoting the positive factors and eliminating the negative factors from the human body and thus regarded as the fourth principal form of the conventional cancer treatment [134]. G. lucidium (Fr.) Karst is believed to act as an antiinflammatory agent [121]; acts as antidiabatic [124]. It is also used by Indian tribals for treating joint pain [45].

[47] revealed various medicinal uses of mushrooms like reishi, cordyceps, enoki, maitake, lion's mane and splitgill for cancer treatment; shiitake, blazei, reishi, enoki, cordyceps, maitake, mesima and oyster were observed effective against cholesterol reduction. Reishi, cordyceps, shiitake and maitake is used for reducing stress. Lion's mane has been used for memory improvement; reishi for inducing sleep, cordyceps for physical endurance and sexual performance, reishi, cordyceps, chaga and lion's mane for asthma and allergy treatment. Shiitake, cordyceps, chaga, shiitake and turkey tail as liver protectants; reshi, maitake, turkey tail and shitake for treating diabetes. It is also believed to be a good health elevator [89]. Auricularia species were used since times for treating hemorrhoids and various stomach ailments [24]. PSK, an anticancer drug from the mushroom, Coriolus versicolor accounted for $25.5 \%$ of the country's total sales in Japan in 1987 as anticancer drug [24].

Mushroom is indeed an option to substitute expensive commodity which are also rich in nutients. In addition, due to its cheap production materials, the commodity can be produced easily by local farmers Thus, the production of the produce is encouraged and considered significant in achieving health and development.

\section{MATERIALS AND METHODS}

\section{A. Research Design}

The experiment was laid out using Completely Randomized Design (CRD) with four treatments. Each treatment was replicated five (5) times. There were three (3) substrates used in the study such as sawdust, corn cob, and rice straw. Randomization was done through drawing of lots. Shown below are the treatments. 


\begin{tabular}{|c|c|}
\hline Treatments & Description \\
\hline $\mathbf{T}_{\mathbf{1}}$ & $=100 \%$ rice straw \\
\hline $\mathbf{T}_{\mathbf{2}}$ & $=100 \%$ corn cob \\
\hline $\mathbf{T}_{\mathbf{3}}$ & $=100 \%$ sawdust \\
\hline $\mathbf{T}_{\mathbf{4}}$ & $=33.33 \%$ rice straw $+33.33 \%$ corn cob + \\
& $33.33 \%$ sawdust \\
\hline
\end{tabular}

*Treatment $(T)$

Table 1

\section{B. Materials}

The following materials were used in this study: polypropylene bags clear/ transparent, cotton plug (vonel), piece of paper, rubber band, metallic drum, source of heat (firewood), PVC pipe (1"diameter x 1" long), sprayer, weighing scale, record notebook, ballpen, and calculator.

\section{Cultural Practices}

$>$ Mushroom House. An area of 30 square meters was utilized. It was thoroughly prepared with air vents on upper walls to facilitate aeration which was highly needed for the development of fruiting bodies and also served as the light source inside the house. The walls were covered with plastic sheets to provide appropriate humidity needed.

$>$ Substrates' Preparation. The substrates were chopped into small pieces of 1-2 inches except for the sawdust. It was soaked for 24 hours in a drum filled with water and after that, was pulled out from the drum for draining the excess water. The substrates were mixed thoroughly by manual handling.

$>$ Fruiting Bag Preparation. The substrates were individually sterilized by steam using metallic drum for 3 hours and allowed to cool to normal temperature.

$>$ Maintenance. This was done by a proper and good hygiene before and after spawning to avoid contamination and to prevent the adverse attack of pest. Close monitoring of the crop on a daily basis was done to prevent pests' infestation and diseases infection.

> Harvesting. Four days after opening the fruiting bags, mushroom was ready for harvest. Mushrooms were picked at the bottom, cup or flat stage depending on the market requirements. The fruiting bodies were harvested by hand with a twisting motion.

\section{Data Gathring Procedures}

All fruiting bags per treatment were considered as the sample. The oyster mushroom from the four treatments were harvested at the same date to identify yield differences. The data collected were the following:

Average Number of Oyster Mushrooms per Fruiting Bag per Treatment. The average number of oyster mushrooms per fruiting bag per treatment was added and divided by the total number of sample bags per treatment.
Average Weight of Oyster Mushroom per Fruiting Bag per Treatment (in grams). The average weight of oyster mushroom in grams per fruiting bag per treatment was weighed using the weighing scale and it was added to get the total weight and divided by the number of sample bag per roped bag per treatment.

$>$ Total Number of Mushrooms per Fruiting Bag per Treatment. The total number of mushroom per roped bag per treatment was counted and it was added to get the sum.

$>$ Total Weight of Oyster Mushrooms per Fruiting Bag per Treatment (in kilogram). The total weight of oyster mushroom per fruiting bag per treatment was weighed using the weighing scale and it was counted and added to obtain the total weight.

\section{E. Data Analysis}

Analysis of Variance (ANOVA) for Completely Randomized Design (CRD) were used as tool in determining the results of the study. The Scheffe method was used to determine which of the different substrates of oyster mushroom would give the highest yield.

\section{RESULTS AND DISCUSSION}

\section{A. Average Number of Oyster Mushroom per Fruiting Bag per Treatment of $\mathrm{H} 1, \mathrm{H} 2, \mathrm{H} 3, \mathrm{H} 4$, and $\mathrm{H} 5$}

H1. Result of the study shows that $\mathrm{T}_{3}$ achieved 33.72, the highest average number of Oyster Mushroom per fruiting bag per treatment, followed by $\mathrm{T}_{4}$ which obtained an average number of 25.88 , followed by $T_{1}$ with the average number of 19.92 and the lowest average number was obtained from $\mathrm{T}_{2}$ (18.84).

H2. Result shows that $T_{2}$ had the highest average number of 17.44 , followed by $\mathrm{T}_{3}$ which had the average number of 17.20 , followed by $T_{1}$ with the average number of 16.80 and the lowest average number of 12.40 was obtained from $\mathrm{T}_{4}$.

H3. Figure 1 presents the average number of oyster mushroom per fruiting bag per treatment. Result shows that $\mathrm{T}_{4}$ had the highest average number of 18.64 , followed by $\mathrm{T}_{1}$ which obtained the average number of 16.60 , followed by $\mathrm{T}_{2}$ with the average number of 16.16 and the lowest average number of 16.12 was obtained from $\mathrm{T}_{3}$.

H4. Result shows that $T_{1}$ had the highest average number of 17.68 , followed by $\mathrm{T}_{2}$ which obtained an average number of 11.16 , followed by $\mathrm{T}_{4}$ with the average number of 10.12 and the lowest average number of 9.88 was obtained from $\mathrm{T}_{3}$.

H5. Result shows that $T_{1}$ obtained the highest average number of 12.64 , followed by $\mathrm{T}_{3}$ which achieved the average number of 11.64 , followed by $\mathrm{T}_{2}$ with the average number of 8.36 and the lowest average number of 8.12 was obtained from $\mathrm{T}_{4}$. 


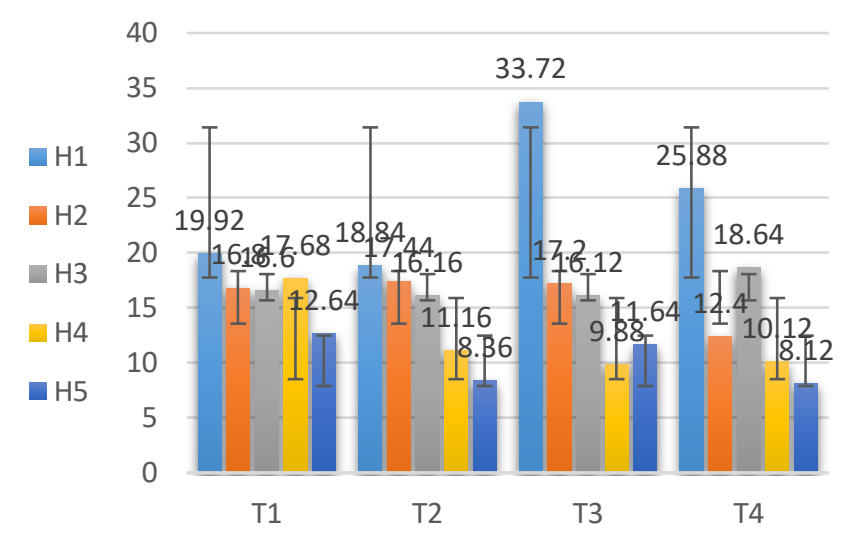

Fig 1:- Average Number of Oyster Mushroom per Fruiting Bag per Treatment from $\mathrm{H}_{1}$ to $\mathrm{H}_{5}$

Legend:

H1 - First Harvest

H2 - Second Harvest

H3 - Third Harvest

H4 - Fourth Harvest

H5 - Fifth Harvest

\section{B. Average Weight of Oyster Mushroom in Grams per Fruiting Bag per Treatment.}

H1. Figure 2 shows the average weight of oyster mushroom in grams per fruiting bag per treatment. Result shows that $T_{3}$ obtained the highest average weight of 102 grams, followed by $\mathrm{T}_{2}$ which obtained the average weight of 96 grams, followed by $\mathrm{T}_{4}$ with the average weight of 94 grams and the lowest average weight of 90 grams was obtained from $\mathrm{T}_{1}$.

H2. Result shows that $\mathrm{T}_{4}$ achieved the highest average weight of 98 grams, followed by $\mathrm{T}_{3}$ which obtained the average weight of 92 grams, followed by $T_{1}$ with the average weight of 90 grams and the lowest average weight of 84 grams was obtained from $\mathrm{T}_{2}$.

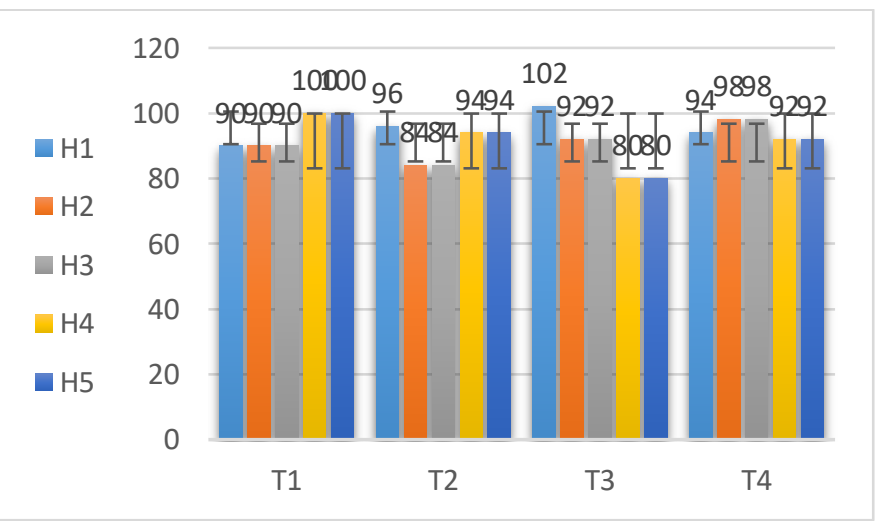

Fig 2:- Average Weight of Oyster Mushroom in Grams per Fruiting Bag per Treatment from $\mathrm{H}_{1}$ to $\mathrm{H}_{5}$

H3. Result showed that $\mathrm{T}_{4}$ obtained the highest average weight of 98 grams, followed by $\mathrm{T}_{3}$ which achieved the average weight of 92 grams, followed by $T_{1}$ with the average weight 90 grams and the lowest average weight of 84 grams was obtained from $\mathrm{T}_{2}$.
H4. Figure 2 revealed the average weight of oyster mushroom in grams per fruiting bag per treatment. Result showed that $T_{1}$ obtained the highest average weight of 100 grams, followed by $\mathrm{T}_{2}$ which obtained the average weight of 94 grams, followed by $\mathrm{T}_{4}$ with the average weight of 92 grams and the lowest average weight of 80 grams was obtained from $\mathrm{T}_{3}$.

H5. Result showed that $T_{1}$ obtained the highest average weight of 106 grams, followed by $T_{2}$ which obtained the average weight of 94 grams, followed by $\mathrm{T}_{3}$ with the average weight of 80 grams and the lowest average weight of 70 grams was obtained from $\mathrm{T}_{4}$.

\section{Total Number of Oyster Mushroom per Fruiting Bag per Treatment.}

H1. Figure 3 presents the total number of oyster mushroom per fruiting bag per treatment. $\mathrm{T}_{3}$ obtained the highest number with a total of 803 , followed by $\mathrm{T}_{4}$ which obtained a total of 548 , followed $\mathrm{T}_{1}$ with a total number of 498 and lowest total number of Oyster Mushroom was obtained from $\mathrm{T}_{2}$ having 471 .

H2. Result shows that $T_{3}$ obtained the highest number with a total of 450 , followed by $\mathrm{T}_{2}$ which obtained a total of 436 , followed by $\mathrm{T}_{1}$ with a total number of 435 and the lowest number was obtained from $\mathrm{T}_{4}$ having 367 .

H3. Result of the study shows that $\mathrm{T}_{4}$ obtained the highest number with a total of 540 , followed by $\mathrm{T}_{2}$ which obtained a total of 500 , followed by $\mathrm{T}_{3}$ which obtained a total of 480 and the shorter number of total was obtained from $\mathrm{T}_{1}$ having a total of 450 .

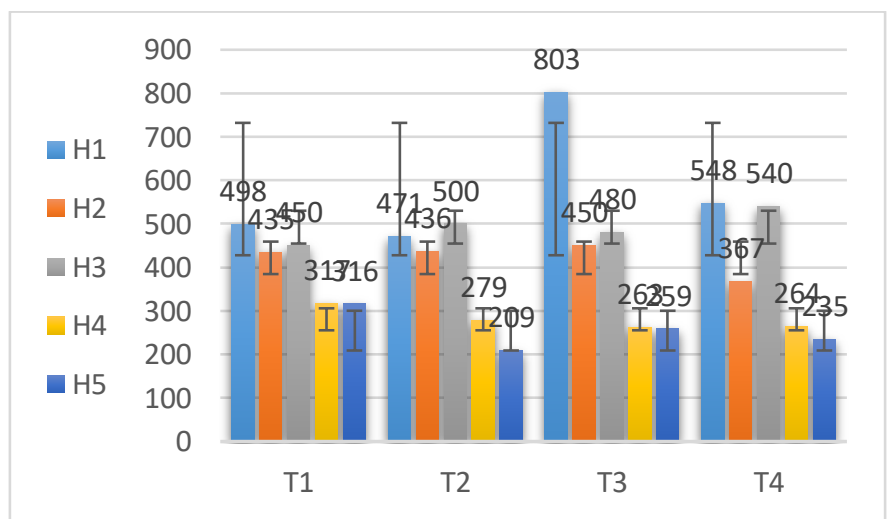

Fig 3:- Total Number of Oyster Mushroom per Fruiting Bag per Treatment from $\mathrm{H}_{1}$ to $\mathrm{H}_{5}$

H4. Figure 3 presents the total number of oyster mushroom per fruiting bag per treatment. It revealed that $\mathrm{T}_{1}$ obtained the highest number with a total of 317 , followed by $T_{2}$ which obtained a total of 279 , followed by $T_{4}$ which obtained a total of 264 and shorter number of total was obtained from $\mathrm{T}_{3}$ having 236 .

H5. Result of the study showed that $T_{1}$ obtained the highest total number with a total of 316 , Followed by $\mathrm{T}_{3}$ which obtained a total number of 259 , followed by $\mathrm{T}_{4}$ 
which obtained a total number of 235 and the lowest total number was obtained from $\mathrm{T}_{2}$ having 209.

\section{Total Weight of Oyster Mushroom in Kilograms per Fruiting Bag per Treatment.}

H1. Figure 4 presents the total weight of oyster mushroom in kilogram per fruiting bag per treatment. Figure 4 shows that $\mathrm{T}_{3}$ obtained the heaviest total weight of $2.30 \mathrm{~kg}$, followed by $\mathrm{T}_{1}$ with $2.25 \mathrm{~kg}$, followed by $\mathrm{T}_{2}$ with the total weight of $2.10 \mathrm{~kg}$, and the lowest total weight of $2.00 \mathrm{~kg}$ was obtained by $\mathrm{T}_{4}$.

H2. Figure 4 shows that $T_{3}$ obtained the heaviest total weight of $2.55 \mathrm{~kg}$, followed by $\mathrm{T}_{2}$ and $\mathrm{T}_{4}$ with a total weight of $2.35 \mathrm{~kg}$. Whereas, $\mathrm{T}_{1}$ obtained the lowest total weight among the four treatments having $2.25 \mathrm{~kg}$.

H3. Result of the study reveals that $\mathrm{T}_{2}$ and $\mathrm{T}_{4}$ obtained the heaviest total weight of $2.50 \mathrm{~kg}$, followed by $\mathrm{T}_{3}$ with a total weight of $2.40 \mathrm{~kg}$. Whereas, $\mathrm{T}_{1}$ obtained the lowest total weight among the four treatments having $2.25 \mathrm{~kg}$.

H4. Result shows that $T_{1}$ obtained the heaviest total weight of $2.50 \mathrm{~kg}$ followed by $\mathrm{T}_{4}$ with a total weight of 2.30 $\mathrm{kg}$, followed by $\mathrm{T}_{2}$ with the total weight of $2.20 \mathrm{~kg}$ and the lowest total weight among the four treatments having 2.05 $\mathrm{kg}$ was obtained from $\mathrm{T}_{3}$.

H5. Figure 4 presents the total weight of oyster mushroom in kilogram per fruiting bag per treatment. Result shows that $\mathrm{T}_{1}$ obtained the heaviest total weight of $2.65 \mathrm{~kg}$, followed by $\mathrm{T}_{2}$ with a total weight of $2.35 \mathrm{~kg}$. On the other hand, $\mathrm{T}_{3}$ and $\mathrm{T}_{4}$ obtained the lowest total weight among the four treatments having $1.90 \mathrm{~kg}$.

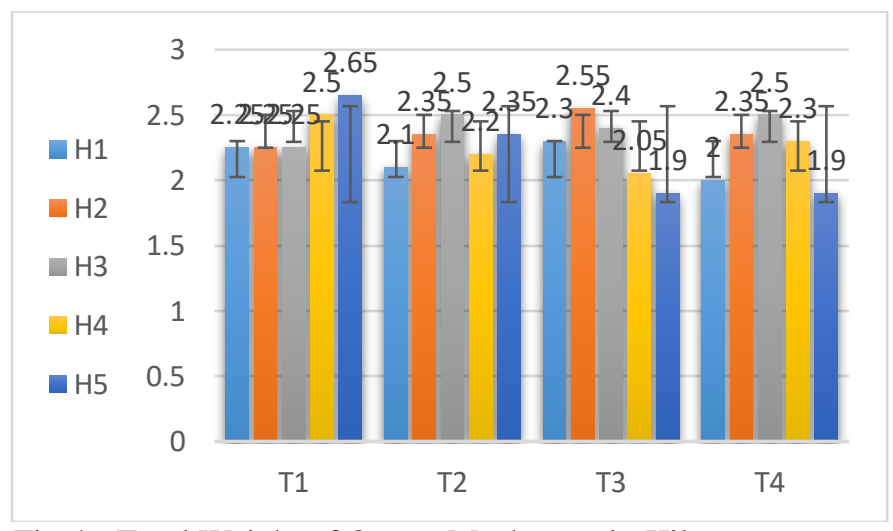

Fig 4:- Total Weight of Oyster Mushroom in Kilograms per Fruiting Bag per Treatment from $\mathrm{H}_{1}$ to $\mathrm{H}_{5}$

\section{CONCLUSION}

Based on the result and analysis of the study, the following conclusions were drawn:

There was a significant difference on the average number of oyster mushroom per fruiting bag per treatment and total number of oyster mushroom per fruiting bag per treatment. However, there were no significant differences on the average weight in grams per fruiting bag per treatment and total weight in kilogram per fruiting bag per treatment for $\mathrm{H} 1$.

There were no significant differences on the average number of oyster mushroom per fruiting bag per treatment for $\mathrm{H} 2, \mathrm{H} 3, \mathrm{H} 4$ and $\mathrm{H} 5$.

There were no significant differences on the average weight of oyster mushroom in grams per fruiting bag per treatment for the $\mathrm{H} 2, \mathrm{H} 3, \mathrm{H} 4$ and $\mathrm{H} 5$.

There were no significance differences on the total number of oyster mushroom per fruiting bag per treatment for the $\mathrm{H} 2, \mathrm{H} 3, \mathrm{H} 4$ and $\mathrm{H} 5$.

There were no significance differences on the total weight of oyster mushroom in kilogram per fruiting bag per treatment for the $\mathrm{H} 2, \mathrm{H} 3, \mathrm{H} 4$, and $\mathrm{H} 5$.

\section{RECOMMENDATIONS}

Based on the previous findings and conclusions, the following are recommended:

$>$ The adoption of $\mathrm{T}_{3}$ to obtain more number of oyster mushroom per fruiting bag per treatment.

$>$ To have a significant yield of oyster mushroom, the adoption of $\mathrm{T}_{3}$ is recommended.

$>$ The use of rice straw and sawdust as substrates to gain more yield on the performance of Oyster Mushroom is also recommended.

\section{REFERENCES}

[1]. Abou-Heilah AN, Kasionalsim MY, Khaliel AS (1987). Chemical composition of the fruiting bodies of Agaricus bisporus. Int. J. Expt. Bot., 47: 64-68.

[2]. Aletor VA (1995). Compositional studies on edible tropical species of mushrooms. Food Chem., 54: 265-268.

[3]. Aletor VA, Aladetimi OO (1995). Compositional studies on edible tropical species of mushrooms. Food Chem., 54: 265-268.

[4]. Alofe FV, Odeyemi O, Oke OL (1995). Three edible mushrooms from Nigeria: Their proximate and mineral composition. Plant Foods for Hum. Nutr., 49: 63-73.

[5]. Anderson EE, Fellers CR (1942). The food value of mushrooms (A Campestris). Proc. Am. Soc. Hort. Sci., 41: 301.

[6]. Atkinson CF (1961). Studies of American Fungi Mushrooms Edible, Poisonous, Hafner publishing Co, New York, pp. 322.

[7]. Bahl N (1983). Medicinal value of edible fungi. In: Proceeding of the International Conference on Science and Cultivation Technology of Edible Fungi. Indian Mushroom Science II, pp. 203-209.

[8]. Bano $\mathrm{Z}$ (1976). Nutritive value of Indian mushrooms and medicinal practices. Eco. Bot., 31: 367-371. 
[9]. Bano Z, Rajarathanam S (1982). Pleurotus mushrooms as a nutritious food. In: Tropical mushrooms -Biological Nature and cultivation methods, (Chang ST, Quimio, TH, eds.) The Chinese University press, Hongkong, pp. 363-382.

[10]. Bano Z, Rajarathanum S (1988). Pleurotus mushroom part II. Chemical composition nutritional value, post-harvest physiology, preservation and role as human food crit. Rev. Food Sci. Nutr., 27: 87158.

[11]. Bano Z, Ahmed R, Srivastava HC (1964). Amino acids of edible mushrooms, Lepiota $\mathrm{sp}$. and Termitomyces sp. Indian j. Chem., 2: 380-381.

[12]. Bano Z, Bhagya S, Srinivasan KS (1981). Essential amino acid composition and proximate analysis of Mushroom, Pleurotus florida. Mushrooms News Lett. Trop., 1: 6-10.

[13]. Bano Z, Srinivasan KS, Srivastava HC (1963). Amino acid composition of the protein from a mushroom (Pleurotus flabellatus). Appl. Microbiol., 11: 184-187.

[14]. Block SS, Stearns TW, Stephens RH, McCandless RFJ. (1953). Mushroom mycelium experiments with submerged culture. J. Agr. Food Chem., 1: 890-893.

[15]. Bobek P, Ozdin L, Kuniak L (1996). Effect of oyster mushroom (Pleurotus ostreatus) and its ethanolic extract in diet on absorption and turnover of cholesterol in hypercholesterolemic rat. Nahrung, 40: 222-224.

[16]. Borchers AT, Stern JS, Hackman RM (1999). Mushrooms, tumors, and immunity. Proc. Soc. Exp. Biol. Med., 221: 281-293.

[17]. Breene WM (1990). Nutritional and medicinal value of speciality mushrooms. J. Food Protect., 53: 883894.

[18]. Buller AHR (1915). The fungus lore of the Greeks and Romans. Trans. Br. Mycol. Soc., 5: 21-26.

[19]. Buswell JA, Chang ST (1993). Edible mushrooms attributes and applications. In: Genetics and breeding of edible mushrooms (Chang, S.T.J. Buswell, J.A and Miles PG (Eds). Gordon and Breach, Philadelphia, pp. 297-394.

[20]. Chandalia M, Garg A, Lutjohann D, von Bergmann K, Grundy SM, Brinkley LJ (2000). Beneficial effects of high dietary fiber intake in patients with type 2 diabetes mellitus. N. Eng. J. Med., 342:13921398.

[21]. Chang ST (1980). Mushroom as human food, Bio Science 30: 339-401.

[22]. Chang, S.T. (1982). Prospects for mushroom protein in developing countries. In: Tropical Mushroom - Biological Nature and Cultivation Methods (Chang ST, Quimio TH. eds.), Chinese University Press, Hong Kong, pp. 463-473.

[23]. Chang ST (1990). Future trends in cultivation of alternative mushrooms. Mush. J. 215: 422-423.

[24]. Chang ST, Buswell JA (1996). Mushroom Nutriceuticals. World J. Microbiol. Biotechnol., 12: 473-476.

[25]. Chang ST, Miles PG (1992). Mushroom biology - A new decipline. Mycologist, 6: 64-65.
[26]. Chihara G, Maeda Y, Hamuro J, Sasaki T, Fukuoka F (1969). Inhibition of mouse sarcoma 180 by polysaccharides from Lentinus edodes (Berk.) Sing. Nature, 222: 687-688.

[27]. Cooke RC (1977). Fungi, Man, and his Environment, Largman, London, New York, pp. 144.

[28]. Crisan EW, Sands (1978). A Nutritional value. In: Chang ST and Hayes WA (eds.). The biology and cultivation of edible mushrooms. Academic press, New York, pp. 172-189.

[29]. Delena T (1999). Edible and useful plants of Texas and South west - A practical guide university of Texas press, pp. 542.

[30]. Demirbas A (2001). Concentrations of 21 metals in 18 species of mushrooms growing in the east Black Sea region. Food Chem., 75: 453-457.

[31]. Dreyfuss MM, Chapela IH (1994). Potential of fungi in the discovery of natural products with therapeutic potential (Gull, V.P. ed.) Bulterworth- Heinemann, Boston MA, pp. 49-80.

[32]. Esselen WB, Fellers CR (1946). Mushrooms for food and flavor. Bull. Mass. Agric. Exp. Sta., p 434.

[33]. Fasidi IA, Olorunmaiye KS (1994). Studies on the requirements for vegetative growth of Pleurotus tuber regium (Fr) Singer. Mushroom Food Chem., 50: 397-401.

[34]. Fasidi IO, Kadiri M (1990a). Changes in nutrient contents of two Nigerian mushrooms. Termitomyces robusts (Beeli) Heim and Lentinus subnudus (Berk), during sporophore development. Die Nahrung, 34: 141-420.

[35]. Feng W, Nagai J, Ikekawa T (2001). A clinical pilot study of EEM for advanced cancer treatment with EEM for improvement of cachexia and immune function compared with MPA. Biotherapy, 15: 691696.

[36]. Ferreira ICFR, Baptista P, Vilas-Boas M, Barros L (2007). Free-radical scavenging capacity and reducing power of wild edible mushrooms from northeast Portugal: individual cap and stipe activity. Food Chem., 100: 1511-1516.

[37]. Florezak J, Karmnska A, Wedzisz A (2004). Comparision of the chemical contents of the selected wild growing mushrooms. Bromatol. Chem. Toksykol., 37: 365-371.

[38]. Florezak J, Lasota W (1995). Cadmium uptake and binding by artificially cultivated cultivated (Pleurotus ostreatus). Bromatol. Chem. Toksykol., 28: 17-23.

[39]. Friedman M (1996). Nutritional value of proteins from different food sources. A review J. Agric. Food Chem., 44: 6-29.

[40]. Gareth JEB (1990). Edible Mushrooms in Singapore and other South East Asian countries. The Mycologist, 4: 119-124.

[41]. Gruen VEC, Wong HX (1982). Immunodulatory and Antitumour activities of a polysaccharidepeptide complex from a mycelial culture of Trichoderma sp. Sciences, 57: 269-281. 
[42]. Gunde-Cimmerman N (1999). Medicinal value of the genus Pleurotus (fr). P Karst (Agaricales s.l. Basidiomycetes). Int. J. Med. Mush., 1: 69-80.

[43]. Gupta S, Sing SP (1991). Nutritive value of mushroom Podaxis pistillaris. Indian J. Mycol. Plant Pathol., 21: 275-276.

[44]. Hadded NA, Hayes WA (1978). Nutritional factors and the composition of the Agaricus bisporus mycelium. Mushroom Science, 10: 715-722.

[45]. Harsh NSK, Rai BK, Tiwari DP (1993). Use of Ganoderma lucidum in folk medicine. J. Trop. Biodivers., 1: 324-326.

[46]. Hayes WA, Haddad N (1976). The food value of the cultivated mushrooms and its importance in industry. Mushroom J., 40: 104110.

[47]. Hobbs C (1995). Medicinal mushrooms. an exploration of tradition, healing and culture, Botanica Press, 10226, Empire Grade, Santa Cruz, CA, 95060.

[48]. Houghton W (1995). Notices of fungi in the Greek and Latin Author Ann. Mag. Nat. His., 15: 22-29.

[49]. Hugaes DH (1962). Preliminary Characterization of the lipid constituents of the cultivated mushroom Agaricus campestris. Mush. Sci., 5: 540546.

[50]. Humfeld H (1948). The production of mushroom mycelia (Agaricus campestris) in submerged culture. Science, 107: 373.

[51]. Humfeld H, Sugihara TF (1949). Mushroom mycelium production by submerged propagation. Food Technol. 3: 355-356.

[52]. Ikekawa T, Uehara N, Maeda Y, Nakanishi M, Fukuoka F (1969). Antitumor activity of aqueous extracts of edible mushrooms. Cancer Res., 29: 734 175.

[53]. Issilogglu M, Yilmaz F, Merdivan M (2001). Concentrations of trace elements in wild edible mushrooms. Food Chem., 73: 163-175.

[54]. Jandaik CL, Kapoor JN (1975). Cultural studies on some edible fungi. Indian J. Mushrooms, 1: 22-26.

[55]. Jiskani MM (2001). Energy potential of mushrooms. Dawn Econ. Bus. Rev., p. 4.

[56]. Jones S, Janardhanan KK (2000). Antioxidant and antitumor activity of Ganoderma lucidum (curt ex Fr.). P. Karst-Reshi (Aphyllophoromycetieae) from south India. Int. J. Med. Mushrooms, 2: 195-200.

[57]. Jong SC, Birmingham JM (1991). Medicinal benefits of the mushroom Ganoderma. Adv. Appl. Microbiol., 37: 101-134.

[58]. Kabir Y, Kimura S, Tamura T (1988). Dietary effect of Ganoderma lucidum mushroom on blood pressure and lipid levels in spontaneously hypertensive rats (SHR). J. Nutr. Sci. Vitaminol., 34: 433-438.

[59]. Kalac P, Svoboda L (2000). A review of trace element concentrations in edible mushrooms. Food Chem., 69: 273-281.

[60]. Kallman S (1991). Nutritive value of Swedish wild plants. Svensk Bot. Tidskr., 85: 397-406.

[61]. Kanwar N, Sharma BM, Sing BM (1990). Nutritive value of Amanita caesarea (Scop. ex. Fr.) Quel. Indian J. Mycol. Plant Pathol., 20: 249-250.
[62]. Kaul TN (1978). Nutritive value of some edible Morchellaceae. Ind. J. Mushroom, 4: 26-34.

[63]. Kidd PM (2000). The use of mushroom glucans and proteoglycans in cancer therapy. Alternative Med. Rev., 5: 4-27.

[64]. Kim BK, Kim HW, Choi EC (1993). Anti-HIV activity of Ganoderma lucidum. J. Biol. Chem., 264: 472-478.

[65]. Kim KC, Kim IG (1999). Ganoderma lucidum extract protects DNA from strand breakage caused by hydroxyl radical and UV irradiation. Int. J. Mol. Med., 4: 273-277.

[66]. Kimura Y, Tojima H, Fukase S (1994). Clinical evaluation of sizofilan as assistant immunotherapy in treatment of head and neck cancer. Acta Otolaryngol., 511: 192-195.

[67]. King TA (1993). Mushrooms, the ultimate health food but little research in $U$. $S$ to prove it. Mushroom News, 41: 29-46.

[68]. Kino KY, Yamaoka K., Watanabe J, Kotk SK, Tsunoo H (1989). Isolation and characterization of a new immunomodulatory protein Zhi-8 (LZ-8) from Ganoderma lucidum. J. Biol. Chem., 264: 472478.

[69]. Lakshmi B, Tilak JC, Adhikari S, Devasagayan TPA, Janardhanan KK (2005). Evaluation of antioxidant activity of selected Indian mushrooms" Inter J. Pharm. Biol., 42: 179-185.

[70]. Lambert EB (1938). Principles and problems of mushroom culture. Bot. Rev., 4: 397-426.

[71]. Latifah AL, Abu Bakar MD, Abu BM (1996). Relative distribution of minerals in the pileus and stalk of some selected edible mushrooms. Food Chem., 56: 115-121.

[72]. Li GSF, Chang ST (1982). Nutritive value of Volvariella volvacea, In: Tropical mushrooms Biological nature and cultivation methods (Chang ST, Quimio TH (eds)) Chinese university press Hong Kong, pp. 199-219.

[73]. Lintzel W (1941). The nutritional value of edible mushroom proteins. Biochem. Acta., 308: 413-419.

[74]. Lintzel W (1943). Uber the nutritive value of protein essbarrer pliz, Chem. Ztg., 67: 33-34.

[75]. Litchfield JH (1964). Nutrient content of morel mushroom mycelium: B vitamin composition. J. Food Sci., 29: 690-691.

[76]. Litchfield JH, Vely VG, Overbeck RC (1963). Nutrient content of morel mushroom mycelium: Aminoacid composition of the protein. J. Food Sci., 28: 741.

[77]. Liu FO, Chang ST (1995). Antitumor components of culture filtrates from Tricholoma sp. World J. Microbiol. Biotechnol., 11: 486-490.

[78]. Maggioni A, Passera C, Renosto F, Benetti E (1968). Composition of cultivated mushrooms (Agaricus bisporous) during the growing cycle as affected by the nitrogen source in compositing. J. Agr. Chem., 16: 517-519.

[79]. Malinowska E, Szefer P, Faradays J (2004). Metals bioaccumulation by bay Bolete, Xerocomos badius from selected sites. Poland Food Chem., 84: 405416. 
[80]. Manning K (1985). Food value and chemical composition. Flegg PB Spencer DM, Wood DA (Eds). The biology and technology of the cultivated Mushroom. John Willey and sons, New York, pp. 221-230.

[81]. Manzi PA, Agguzzi A, Pizzoferrato L (2001). Nutritional mushrooms widely consumed in Italy. Food Chem., 73: 321-325.

[82]. Manzi PS, Marconi Aguzzi A, Pizzoferrato L (2004). Commercial mushroom nutritional quality and effect of cooking. Food Chem., 84: 201-2006.

[83]. Mattila P, Konko K, Eurola M, Pihlawa JM, Astola $\mathrm{J}$, Vahteristo Lietaniemi V, Kumpulainen J, Valtonen M, Piironen V (2001). Contents of vitamins, mineral elements, and some phenolic compounds in cultivated mushrooms. J. Agric. Food Chem., 49: 2343-2348.

[84]. Mattila PH, Piironen VI, Uusi- R, Koivistoinen, PE (1994). Vit. D contents in edible mush. J. Agr. Food Chem., 42: 2449-2453.

[85]. Mattila PK, Konko M, Eurola J, Pihlava J, Astola L, Vahteristo V, Hietaniemi J, Kumpulainen N, Valtonen V, Piironen V (2000). Contents of vitamins, mineral elements and some phenolic compounds in the cultivated mushrooms. J. Agric. Food Chem., 49: 2343-2348.

[86]. Mau CN, Huang SJ, Chen CC (2004). Antioxidant properties of methanolic extracts from Grifola frondosa, Morchella esculenta and Termitomyces albuminosus mycelia. Food Chem., 87: 111-118.

[87]. Mc Connel JE, Esselen WB (1947). Carbohydrate in cultivated mushrooms. Food Res., 12: 118-121.

[88]. [88] Mejstric V, Lepsova A (1993). Applicability of fungi to the monitoring of environmental pollution by heavy metals. In: B. Markert (ed) Plants as biomonitors. Germany: VCH weinheim, pp. $365-$ 378

[89]. [89] Mizuno T (1996). Oriental medicinal tradition of Ganoderma lucidum (Reishi) in India. In: Ganoderma lucidum (Mizuno,T and Kim,B.K eds.). Li Yang Pharm. Co. Ltd., Seoul, Korea, pp. 101106.

[90]. [90] Nanba H (1993). Maitake mushroom the king mushroom. Mushroom News, 41: 22-25.

[91]. Ohtsuka S, Ueno S, Yoshikumi C, Hirose F, Ohmura Y, Wada T, Fujii T, Takahashi E (1997). Polysaccharides having an anticarcinogenic effect and a method of producing them from species of Basidiomycetes. UK Paten No. 1331513.

[92]. Orgundana SK, Fagade O (1981). The nutritive value of some Nigerian edible mushrooms. In: Mushroom Science XI, Proceedings of the Eleventh International Scientific Congress on the Cultivation of Edible Fungi, Australia, pp. 123-131.

[93]. Oso BA (1997). Pleurotus tuber-regium from Nigeria. Mycologia 69: 271-279.

[94]. Oyetayo FL (2007). Potential antioxidant properties of Nigerian edible mushrooms. Agro food Industry, Hi-tech., 18: 44 -45.

[95]. Oyetayo VO, Oyetayo FL (2005). Preliminary investigation of health promoting potentials of
Lactobacillus fermentum OVL and Plerotus sajor caju administered to rats. Pakistan J. Nutr., 4: 73-77.

[96]. Pedneault KP, Gosselia A, Tweddell RJ (2006). Fatty acid composition of lipids from mushrooms belonging to the family Boletaceae. Mycolog. Res., 110: 1179-1183.

[97]. Przybytniak G, Ambroz H (1999). Free radicals, their identification and determination. In: Marciniec B and Zak S., (eds.) Analytical methods in studies of pollutants and hazardous. Bydgoszcz: BTN, p. 17.

[98]. Purkayastha RP, Chandra A (1976). Amino acid composition of protein of some edible mushroom growth in synthetic medium. J. Food Sci. Technol., 3: 13-17.

[99]. Puttaraju NG, Venkateshaiah SU, Dharmesh SM, Urs SM, Somasundaram R (2006). Antioxidant Activity of Indigenous Edible Mushrooms. J. Agric. Food Chem., 54: 9764-9772.

[100]. Rai RD (1994). Nutritional and medicinal values of mushrooms. In: Advances in Horticulture. (Chadha KL, Sharma SR eds.), Malhotra publishing house, New Delhi, pp. 537-551.

[101]. Rai RD (1997). Medicinal mushrooms. In: Advances in Mushroom Biology and Production (Rai RD, Dhar BL, Verma RN ed.) Mushroom society of India. NRCM, Solan, H.P., pp. 355-368.

[102]. Rai RD, Saxena S (1989a). Biochemical changes during the post harvest storage of button mushroom (Agaricus bisporus). Curr. Sci., 58: 508-10.

[103]. Ren L, Visitev AV, Grekhov AN, Tertov VV, Tutelyan VA (1989). Antiatherosclerotic properties of macrofungi. Voprosy Pictaniya, 1: 16- 19.

[104]. Rolfe RT, Rolfe FW (1925). The Romance of the fungus world. Chapman and Hall Ltd. London, pp. 309.

[105]. Rudawska M, Leski T (2005) Macro and micro elemental contents in fruiting bodies of wild mushrooms from the Netecka forest in west central Poland. Food Chem., 92: 499-502

[106]. Russell R, Paterson M (2006). Ganoderma - A therapeutic fungal factory Phytochemistry. J. Phytochem., 67: 1985-2001.

[107]. Sadler M (2003). Nutritional properties of edible fungi. Br. Nutr. Found. Nutr. Bull. 28: 305-308.

[108]. Sagakami H, Aohi T, Simpson A, Tanuma S (1991). Induction of immunopotentiation activity by a proteinbound polysaccharide, PSK. Anticancer Res., 11: 993-1000.

[109]. Samajipati N (1978). Nutritive value of Indian edible mushrooms. Mushroom Sci., 10: 695-703.

[110]. Samorini G (2001). Fungi Hallucinogeni. Studi etnomicologici. Telesterion. Dozza Ed., Bologna, Italy, Shen (Guo J, Cheng HY, Wei X. eds.), pp. 250

[111]. Sanme RB, Dell, Lumyoung P, Izumori K, Lumyoung S (2003). Nutritive value of popular wild edible mushrooms from Northern Thailand. Food Chem., 82: 527-532.

[112]. Sapers GM, Miller RL, Choi SW, Cooke PH (1999). Structure and composition of mushrooms as affected by hydrogen peroxide wash. J. Food Sci., 64: 889892. 
[113]. Schmitt HW, Sticher H (1991). Heavy metal compounds in soil. In Merian, E (ed.). Metals and their compounds in the environment. Weinheim: VCH Verlagsgessellschaft, pp. 311-326

[114]. Shah H, Iqtidar A, Khalil, Jabeen S (1997). Nutritonal composition and protein quality of Pleurotus mushroom. Sarhad. J. Agric., 13: 621626.

[115]. Sharma RP, Kaisth KR, Lakhanpal TN (1988). Protein and Mineral content of two edible Lactarius species. Ind. J. Mushrooms, 14: 4447.

[116]. Sharma TK (2008). Vegetable caterpillar, Science Reporter. 5th May ISBN 0036-8512. National institute of science communication and information resources (NISCAIR), CSIR, pp. 33-35.

[117]. Shi YL, James AE, Benzie IFF, Buswell JA (2002). Mushroom derivedpreparation in the prevention of $\mathrm{H} 2 \mathrm{O} 2$-induced oxidative damage to cellular DNA. Teratoegensis Carcinogenesis Mutagenesis, 22: 103111.

[118]. Singer R (1961). Mushrooms and Truffles, Leonard Hill Books Ltd., p. 272.

[119]. Singh NB, Singh P (2002). Biochemical Composition of Agaricus bisporus. J. Indian Bot. Soc., 81: 235-237.

[120]. Sohi HS (1988). Mushroom culture in India, Recent research findings. Indian Phytopath, 41: 313-326.

[121]. Stavinoha W, Slana J, Weintraub S, Mobley P (1991). The antiinflammatory activity of Ganoderma lucidum, Third Internationak Symposium on Ganoderma lucidum, Seoul Korea. Pharm. Soc. Korea, pp. 9-21.

[122]. Svoboda L, Zimmermannova K, Kallac P (2001). Concentrations of Mercury, Cadmium, Lead, and Copper in the fruiting bodies of the edible mushrooms in an emission area of a copper smelter and a mercury smelter. Sci. Total Environ., 246: 6167.

[123]. Tanaka M, Kuei CW, Nagashima Y, Taguchi T (1998). Application of antioxidative maillrad reaction products from histidine and glucose to sardine products. Nippon Suisan Gakkaishil, 54: 1409-1414.

[124]. Teow SS (1997). The effective application of Ganoderma nutriceuticals. In: Recent progress in Ganoderma lecidum research (Kim BK, Moon CK, Kim TS eds.). Seoul Korea. Pharm. Soc. Korea, pp. 21-39.

[125]. Tseng YH, Mau JL (1999). Contents of sugars free amino acids and free 5- nucleotides in mushroom, Agaricus bisporus, during the post-harvest storage. J. Sci. Food Agric., 79: 1519-1523.

[126]. Varo P, Lahelman O, Nuurtamo M, Saari E, Koivistoinen P (1980). Mineral element composition of Finish Food. VII Postal, Vegetables, fruits, berries, nuts and mushrooms. Acta Agric. Scandinavica Supplement, 22: 107-113.

[127]. Velioglu YS, Mazza G, Gao L, Oomah BD (1998). Antioxidant activity and total phenolics in selected fruits, vegetables, and grain products. J. Agric. Food Chem., 46: 4113-4117.
[128]. Verma RN, Singh GB, Bilgrami KS (1987). Fleshy fungal flora of N. E. H. India- I. Manipur and Meghalaya. Indian Mush. Sci., 2: 414- 421.

[129]. Wannet WJB, Hermans JHM, Vander Drift C, Op den Camp HJM (2000). HPCL detection of soluble carbohydrates involved in mannitol and trehalose metabolism in the edible mushroom, Agaricus bisporus. J. Agaric. Food Chem., 48: 287-291.

[130]. Wasser SP (2005). Reishi or Lingzhi (Ganoderma lucidum). Encyclopedia of Dietary Supplements, Marcel Dekker, Germany, pp. 603-622.

[131]. Wasser SP, Weis AL (1999). Medicinal properties of substances occurring in higher Basidiomycetes mushrooms: current perspectives (Review). Int. J. Med. Mushrooms, 1: 1-62.

[132]. Weaver KC, Kroger M, Kneebone LR (1977). Comparative protein studies on nine strains of Agaricus bisporus (Lange) J. Food Sci., 42: $364-$ 366.

[133]. Wondratschek I, Roder U (1993). Monitoring of heavy metals in soils by higher fungi.In B. Market (Ed). Plants as biomonitors, pp. 365-378.

[134]. Yang QY, HU YJ, LI XY, Yang SX, LIU JX, Liu TF, XU GM, Liao LM (1993). A New Biological Response Modifier - PSP. (In: CHANG ST, BUSWELL JA, CHIU SW (eds.) Mushroom Biology and Mushroom Products. The Chinese University Press, Hong Kong, pp. 247-259.

[135]. Yilmaz NM, Solamaz I, El mastas M (2006). Fatty acid composition in some wild edible mushrooms growing in the Middle Black region of Turkey. Food Chem., 99: 168-174.

[136]. Yoshioka Y, Ikekawa T, Nida M, Fukuoka F (1975). Studies on antitumor activity of some fractions from basidiomycetes I. An antitumor acidic polysaccharide fraction of Pleurotus ostreatus (Fr.) Quel. Chem. Pharm. Bull., 20: 1175-1180.

[137]. Zakia B, Rajarathnam S (1994). Mushrooms-Human nutrition and health. In: Microbes for better Living. MICON 94, 35th AMI Cong., 912 Nov., pp. 395399.

[138]. Zakia SA, El-Kattan MH, Hussein WA, Khaled AM (1993). Chemical composition and processing potential of oyster mushroom, Pleurotus ostreatus. Egypt J. Agric. Res., 71: 621-631.

[139]. Zhou Z, Lin J, Yin Y, Zhao J, Sun, X, Tang K (2007). Ganodermataceae: Natural products and their related pharmacological functions. Amer. J. Chin. Med., 35: 559-574.

[140]. Zrodlowski Z (1995). The influence of washing and peeling of mushrooms Agaricus bisporus on the level of heavy metal contaminations. Pol. J. Food Nutr. Sci., 4: 23-33. 